\title{
A neuromuscular transmission disorder: combined myasthenia gravis and Lambert Eaton syndrome in one patient
}

\author{
M J B TAPHOORN, * H VAN DUIJN, $†$ ECH WOLTERS* \\ From the Departments of Neurology* and Clinical Neurophysiology, $\uparrow$ Academic Hospital Free University, \\ Amsterdam, the Netherlands
}

SUMMARY The distinction between myasthenia gravis and Lambert Eaton myasthenic syndrome can usually be made by the clinical and neurophysiological features. A patient was observed with features which suggested a combination of both disorders. This has been described in few patients before. The importance of electromyography in both distal and proximal limb muscles for a correct diagnosis is demonstrated. Only in proximal nerve stimulation tests was proof found of the existence of both syndromes.

Myasthenia gravis and Lambert Eaton myasthenic syndrome (LEMS) are both autoimmune diseases with impaired neuromuscular transmission. ${ }^{1-3}$ Apart from similarities there are essential differences in pathogenesis and therapy; myasthenia gravis is a postsynaptic disorder at the acetylcholine receptor level, while LEMS is thought to be caused by a presynaptic membrane defect. ${ }^{4}$ Electromyography is probably essential for making the correct diagnosis as clinical features may not be sufficient to differentiate between the two syndromes. We describe a patient with clinical and neurophysiological features which suggest a combination of both diseases. This has been described in few patients before. ${ }^{5-15}$

Case report (fig, upper part)

In 1984 an 80 year old woman visited our clinic with complaints of fluctuating weakness of ocular, bulbar and limb muscles, which had existed for several months. Apart from the weakness which could be provoked by exertion, neurological examination showed no abnormalities. The tendon reflexes were sluggish. There was no post-tetanic poten-

Address for reprint requests: $M$ J B Taphoorn, MD, Afdeling Neurologie Academisch VU Ziekenhuis, De Boelelaan 1117, 1081 HV, Amsterdam, the Netherlands

Received 4 August 1987 and in revised form 2 December 1987. Accepted 7 December 1987 tiation on clinical testing. In her serum antibodies against acetylcholine receptors were found and the patient was treated with one anticholinesterase agent (mestinon up to $360 \mathrm{mg} / \mathrm{day}$ ). After 6 months she became increasingly dyspnoeaic and was admitted to hospital where her vital capacity proved to be only $1000 \mathrm{ml}$. There was obvious ocular, bulbar and generalised muscle weakness, prominent in pelvic and shoulder girdle. A dry mouth, paraesthesias in the limbs and absent tendon reflexes were noticed. Routine haematological, chemical and serological tests revealed no abnormalities. Antibodies against striated muscle, however, were found in the serum along with thyroid and gastric antibodies. The patient was known to suffer from pernicious anaemia; biopsy specimens from the gastric mucosa showed chronic inflammation without signs of malignancy. Chest radiograph and $\mathrm{CT}$ were negative for a possible thymoma. As the tensilon test $(10 \mathrm{mg}$ i.v.) clinically still resulted in some improvement of muscle strength, neostigmin (45 $\mathrm{mg} /$ day) was added to the mestinon medication. After a few days, signs of a cholinergic overdose developed. Repeated neurophysiological testing revealed abnormal findings which suggested the diagnosis of LEMS (see below). Consequently the patient was treated with corticosteroids (prednisone) up to $60 \mathrm{mg} /$ day, tapering off to a $40 \mathrm{mg}$ alternate day dose. Clinically and neurophysiologically there was marked improvement. The patient was able to eat solid food again, to walk without support, and to take care of herself. At the same time the titre of antibodies against acetylcholine receptors in serum decreased from $42 \mathrm{nmol} / 1$ to $2 \cdot 3$ nmol/l. Extensive investigations, including CT scan of the lungs and the abdomen, for possible malignancy were negative. 

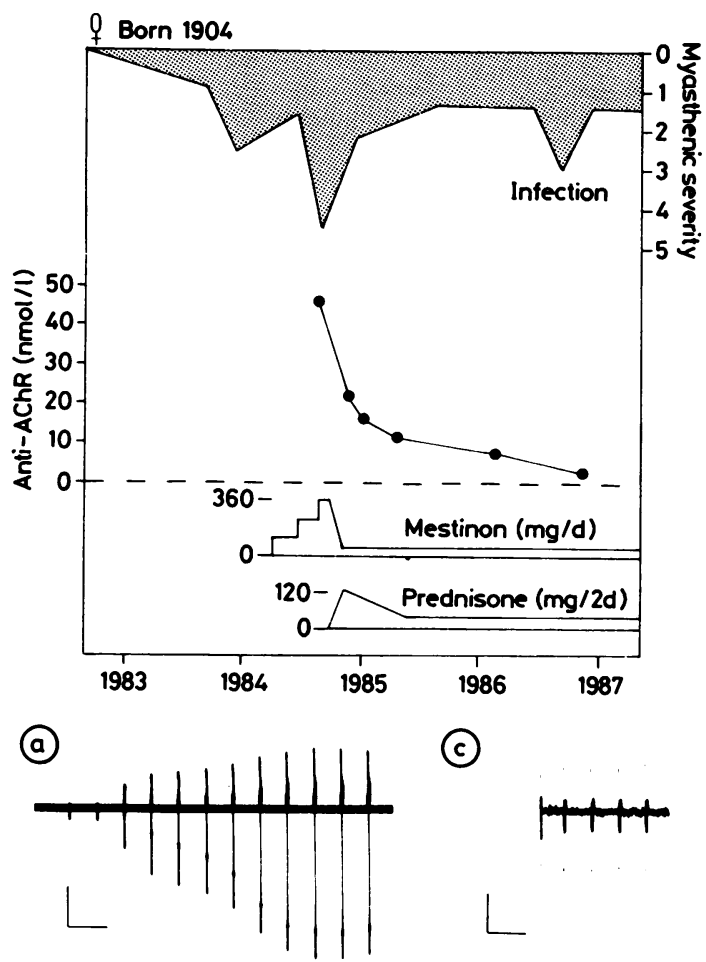

(c)

(b)

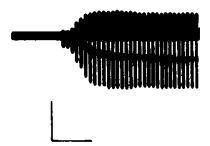

Fig Upper part: Clinical history; for myasthenic severity see Oosterhuis. ${ }^{16}$ Lower part: Repetitive supramaximal stimulation of the musculocutaneous nerve; recording CMAP from the right biceps muscle (a) $3 \mathrm{~Hz}$ stimulation before corticosteroid treatment, (b) $20 \mathrm{~Hz}$ stimulation before corticosteroid treatment, (c) $3 \mathrm{~Hz}$ stimulation after corticosteroid treatment, (d) $20 \mathrm{~Hz}$ stimulation after corticosteroid treatment. Calibrations: horizontal bar $500 \mathrm{~ms}$, vertical bar $5 \mathrm{mV}$.

\section{Electromyographical data}

On neither conventional electromyography nor repetitive supramaximal nerve stimulation were abnormalities in distal limb muscle (right abductor digiti quinti muscle) revealed. In proximal limb muscle, however, conventional electromyography showed some denervation potentials and polyphasic motor unit action potentials. On supramaximal stimulation of the musculocutaneous nerve a small amplitude $(2 \mathrm{mV})$ of the initial compound muscle action potential (CMAP) was seen. Meanwhile the patient received mestinon therapy. Repetitive stimulation at low rate $(3 \mathrm{~Hz})$ resulted in a $1000 \%$ facilitation; at high rate $(20 \mathrm{~Hz})$ facilitation up to
$350 \%$ of the CMAP was recorded (right biceps muscle; fig a, b).

After corticosteroid treatment the amplitude of the initial CMAP increased to a normal level $(12 \mathrm{mV})$. Pathological increment on both low and high rate nerve stimulation were no longer observed (fig c, d).

\section{Discussion}

Neurophysiological testing is an important tool for diagnosis in neuromuscular transmission disorders, even when clinical features may initially appear quite clear. The testing should not be limited to distal limb muscles because proximal limb muscles may be the only site where abnormalities can be found, as has been suggested already by Young and Özdemir. ${ }^{17} 18$

In our patient clinical features in combination with antibodies against acetylcholine receptors suggested myasthenia gravis. These antibodies are found almost exclusively in myasthenia gravis and occasionally in patients with thymoma without myasthenia gravis. ${ }^{19}$ In spite of the combination of antibodies against acetylcholine receptors and striated muscle, known to be associated with thymoma, ${ }^{2}$ no thymoma was found.

In myasthenia gravis neurophysiological testing may show decrease of the CMAP on both low and high rate nerve stimulation. In several patients an incremental response was described on high rate nerve stimulation up to over $100 \% .{ }^{1820}$ A difference in findings between proximal and distal limb muscle is frequently noticed in myasthenia gravis: proximal limb muscle may produce abnormal findings while those in distal limb muscle may be completely normal. ${ }^{17}$ In our patient this difference was found as were abnormal findings on conventional electromyography. However, the initial small amplitude and the incremental response of the CMAP on high rate nerve stimulation strongly suggest LEMS. In this disease facilitation has been described on high rate nerve stimulation from $200 \%$ to $2000 \%$. $^{2122}$ The facilitation on low rate nerve stimulation observed in our patient is exceptional, but has been described before. ${ }^{17}$ The distinction between findings in proximal and distal limb muscle is remarkable and, to our knowledge, has not yet been reported in patients with LEMS.

Neurophysiological testing of proximal limb muscle in our patient, in combination with some clinical aspects (dry mouth, paraesthesias in the limbs and areflexia) clearly indicated LEMS in addition to myasthenia gravis. LEMS is known to occur predominantly in patients with malignant diseases, especially the oat cell carcinoma of the lung. ${ }^{22}$ In few patients has LEMS been described in association with autoimmune disorders. ${ }^{23}{ }^{24}$ Our patient, like Oh's, ${ }^{10}$ was known to have pernicious anaemia as well as 
Table Patients with features of both myasthenia gravis and Lambert Eaton myasthenic syndrome

\begin{tabular}{|c|c|c|c|c|c|c|c|}
\hline \multirow{2}{*}{ Author } & & \multicolumn{2}{|c|}{ Patient } & \multirow{2}{*}{$\begin{array}{l}\text { Clinical } \\
\text { features }\end{array}$} & \multirow{2}{*}{$\begin{array}{l}\text { Neurophysiological } \\
\text { features: facilitation }\end{array}$} & \multirow{2}{*}{$\begin{array}{l}\text { Associated } \\
\text { disorders }\end{array}$} & \multirow[b]{2}{*}{ anti-AChR } \\
\hline & & $\operatorname{sex}$ & age & & & & \\
\hline Takamori $^{15}$ & & $\begin{array}{l}f \\
\mathrm{f} \\
\mathrm{f}\end{array}$ & $\begin{array}{l}33 \\
32 \\
33 \\
56\end{array}$ & $\begin{array}{l}\text { MG/LEMS } \\
\text { MG/LEMS } \\
\text { MG/LEMS } \\
\text { MG/LEMS }\end{array}$ & $\begin{array}{l}80 \%-280 \% \\
\text { (post-tetanic) }\end{array}$ & carcinoma of stomach & \\
\hline Dahl $^{6}$ & & $\mathrm{~m}$ & $\begin{array}{l}13 \\
63\end{array}$ & MG LEMS & $\begin{array}{r}89 \%(20-50 \mathrm{~Hz}) \\
580 \%(20-50 \mathrm{~Hz})\end{array}$ & & \\
\hline Schwartz ${ }^{11}$ & e.a. & f & 47 & MG & $190 \%(20-50 \mathrm{~Hz})$ & & \\
\hline $\begin{array}{l}\text { Mori }{ }^{8} \\
\text { Cherington }\end{array}$ & e.a. & $\mathrm{m}$ & $\begin{array}{l}50 \\
38\end{array}$ & $\begin{array}{l}\text { MG } \\
M G / I F M S\end{array}$ & $96 \%$ (post-tetanic) & hyperthyroidism & \\
\hline Fettel $^{7}$ & e.a. & $\mathrm{m}$ & 58 & MG/LEMS & $>100 \%(20-50 \mathrm{~Hz})$ & oat cell carcinoma of lung & + \\
\hline Singer ${ }^{12}$ & e.a. & f & 58 & MG & $208 \%$ (post-tetanic) & & + \\
\hline Tabbaa $^{13}$ & e.a. & $\mathrm{m}$ & 42 & MG/LEMS & $83 \%$ (post-tetanic) & thymoma & + \\
\hline $\mathrm{Oh}^{10}$ & e.a. & f & 26 & MG/LEMS & $510 \%(20-50 \mathrm{~Hz})$ & pernicious anaemia & + \\
\hline
\end{tabular}

MG = Myasthenia gravis. LEMS = Lambert Eaton syndrome

The second patient described by Takamori had already been described before ${ }^{14}$

myasthenia gravis, both of which are known to be autoimmune disorders. The combination of myasthenia gravis and LEMS has been described in few patients before (table). The determination of antibodies against acetylcholine receptors, a highly specific test for myasthenia gravis, has only been possible since $1976 .{ }^{25}$ Therefore a combination of these diseases would have been less evident in the patients described before 1976.

Corticosteroids are effective in both myasthenia gravis and LEMS. ${ }^{26} 27$ In addition to the systemic effects of corticosteroids there is evidence of a local effect on the neuromuscular junction. ${ }^{28-30}$ Also in our patient this treatment resulted in clinical improvement and normalisation of the neurophysiological findings.

\section{References}

1 Lang B, Newsom-Davis J, Wray D, Vincent A, Murray N. Autoimmune aetiology for myasthenic (Eaton-Lambert) syndrome. Lancet 1981;ii:224-6.

2 Oosterhuis HJGH. Myasthenia Gravis. Clinical neurology and neurosurgery monographs, vol. 5. New York, Churchill Livingstone, 1984:104-30.

3 Patrick J, Lindstrom J. Autoimmune response to acetylcholine receptor. Science 1973;180:871-2.

4 Prior C, Lang B, Wray D, Newsom-Davis J. Action of LambertEaton myasthenic syndrome IgG at mouse motor nerve terminals. Ann Neurol 1985;17:587-92.

5 Cherington M. Guanidine and germine in Eaton-Lambert syndrome. Neurology 1976;26:944-6.

6 Dahl DS, Sato S. Unusual myasthenic state in a teen-age boy. Neurology 1974;24:897-901.

7 Fettel MR, Sin HS, Penn AS, Lovelace RE, Rowland LP. Combined Eaton-Lambert syndrome and myasthenia gravis. $\mathrm{Neu}$ rology 1978;28:398.

8 Mori M, Takamori M. Hyperthyroidism and myasthenia gravis with features of Eaton-Lambert syndrome. Neurology 1976;26:882-7.

9 Oh SJ. The Eaton-Lambert syndrome in ocular myasthenia gravis. Arch. Neurol. 1974;31:183-6.

10 Oh SJ, Dwyer DS, Bradley RJ. Overlap myasthenic syndrome: combined myasthenia gravis and Eaton-Lambert syndrome. Neurology 1987;37:1411-4.

11 Schwartz MS, Stalberg E. Myasthenia gravis with features of the myasthenic syndrome. Neurology 1975;25:80-4.

12 Singer P, Smith L, Ziegler DK, Festoff BW. Post-tetanic poten- tiation in a patient with myasthenia gravis. Neurology 1981;31:1345-7.

13 Tabbaa MA, Leshner RT, Campbell WW. Malignant thymoma with dysautonomia and disordered neuromuscular transmission. Arch Neurol 1986;43:955-7.

14 Takamori M, Gutmann L. Intermittent defect of acetylcholine release in myasthenia gravis. Neurology 1971;21:47-54.

15 Takamori M. Caffeine, calcium and Eaton-Lambert syndrome. Arch Neurol 1972;27:285-91.

16 Oosterhuis HJGH. Myasthenia Gravis. Clinical neurology and neurosurgery monographs, vol. 5. New York, Churchill Livingstone, 1984:46.

17 Özdemir C, Young RR. The results to be expected from electrical testing in the diagnosis of myasthenia gravis. Ann NY Acad Sci 1976;274:203-22.

18 Özdemir C, Young RR. Electrical testing in myasthenia gravis. Ann NY Acad Sci 1971;183:287-302.

19 Vincent A, Newsom-Davis J. Acetylcholine receptor antibody as a diagnostic test for myasthenia gravis: results in 153 validated cases and 2967 diagnostic assays. J Neurol Neurosurg Psychiatry 1985;48:1246-52.

20 Mayer RF, Williams IR. Incrementing responses in myasthenia gravis. Arch Neurol 1974, 31:24-6.

21 Lambert EH, Rooke ED, Eaton LM, Hodgson CH. Myasthenic syndrome occasionally associated with bronchial neoplasm: neurophysiologic studies. In: Viets HR (Ed) Myasthenia Gravis. Springfield, Thomas, 1961:362-410.

22 Lambert EH, Rooke ED. Myasthenic state and lung cancer. In: Brain RW, Norris FH (Eds) The remote effects of Cancer on the Nervous System. New York, Grune \& Stratton, 1965:67-80.

23 Gutmann L, Crosby TW, Takamori M, Martin JD. The EatonLambert syndrome and autoimmune disorders. Am J Med 1972;53:354-6.

24 Lennon VA, Lambert EH, Whittingham S, Fairbanks V. Autoimmunity in the Lambert-Eaton myasthenic syndrome. Muscle Nerve 1982;5:S21-5.

25 Lindstrom JM, Seybold ME, Lennon VA, Whittingham S. Duane DD. Antibody to acetylcholine receptor in myasthenia gravis. Neurology 1976;26:1054-9.

26 Brunner NG, Namba T, Grob D. Corticosteroids in management of severe, generalized myasthenia gravis. Neurology 1972; 22:603-10.

27 Streib EW, Rothner AD. Eaton-Lambert myasthenic syndrome: long-term treatment of three patients with prednisone. Ann Neurol 1981;10:448-53.

28 Noble MD, Peacock JH, Lacher JA, Hofmann WW. Prednisoneneostigmine interactions at cholinergic junctions. Muscle Nerve 1979;2:155-7.

29 Wilson RW, Ward MD, Johns TR. Corticosteroids: a direct effect at the neuromuscular junction. Neurology 1974;24:1091-5.

30 Wolters ECMJ, Leeuwin RS, Van Wijngaarden GK. The effect of prednisolone on the rat phrenic nerve-diaphragm preparation treated with hemicholinium. Eur J Pharmacol 1974;29:165-7. 